\title{
HAK CIPTA BUKAN HANYA COPYRIGHT
}

\author{
Agus Sardjono ${ }^{1}$
}

\begin{abstract}
Abstrak
Under his research the author does elaboration through Hak Cipta and copyright in clearly by those history and implication in practice. This article announces that hak cipta is not copyright eventhough in the inside of hak cipta contained copyright. Hak cipta itself under that history has been truly as revision of copyright doctrine in England. That revision movement was happened in Europe continent under doctrine of justice (of natural law) which says that protection ought to be given to the inventor not to corporations that based on copyright. Then later in implication is not true that corporations aim to taking over all of inventor right even under specific contract. The author convinces that right shall not be alienated from the inventor based freedom of contract principle.
\end{abstract}

Kata kunci: hukum haki, kerancuan, hak cipta, copyright

\section{Pendahuluan}

Menurut sejarahnya, istilah Hak Cipta merupakan penyingkatan dari istilah Hak Pencipta. Istilah ini muncul pertama kali dalam Kongres Kebudayaan tahun 1952 di Bandung. Para pelaku budaya pada masa itu risau dengan istilah Hak Pengarang sebagai terjemahan dari auteursrecht yang terdapat dalam Auteurswet 1912. Menurut peserta Kongres, auteursrecht tidak semata-mata berhubungan dengan karang-mengarang dalam ranah karya sastera (literary) atau karya tulis, melainkan mencakup lingkup yang lebih luas, yaitu cipta-mencipta karya-karya lainnya, termasuk musik, patung, dan karya-karya kebudayaan lainnya. Oleh karena itu, istilah hak pengarang sebagai terjemahan dari auteursrecht harus diganti menjadi istilah Hak Pencipta, yang kemudian disingkat menjadi Hak Cipta. ${ }^{2}$

Auteurswet 1912 sendiri merupakan undang-undang yang lahir di Negeri Belanda, yang kemudian berdasarkan asas konkordansi diberlakukan

\footnotetext{
${ }^{1}$ Penulis adalah Dosen Fakultas Hukum Universitas Indonesia. Alamat korespondensi: sardjono_agus@hotmail.com.

2 Tentang hal ini lihat Ajip Rosidi, "Undang-undang Hak Cipta 1982: Pandangan Seorang Awam", (Jakarta: Djambatan, 1984), hal.3.
} 
pula bagi orang-orang Eropa di negeri jajahannya, (wilayah Nusantara). ${ }^{3}$ Dasar pemberlakuan Auteurswet bagi orang-orang Eropa di tanah Nusantara adalah Pasal 131 ayat (2.a) Indische Staatsregeling (IS). ${ }^{4}$

Sejarah tentang konsep auteursrecht yang diatur di dalam Auteurswet 1912 boleh dikatakan merupakan koreksi dari Copyright Act yang berlaku di Inggris. Sedangkan sejarah copyright di Inggris diawali dengan ditemukannya mesin cetak pada abad XV. Tepatnya pada tahun 1476, William Caxton menemukan mesin cetak tersebut. Dengan ditemukannya mesin cetak itu mempermudah proses perbanyakan (copy) suatu karya tulis, karena tidak harus menyalin ulang dengan menggunakan pena atau alat tulis lainnya.

Munculnya mesin cetak membawa akibat munculnya industri percetakan (printing industry). Bukan hanya itu, munculnya mesin cetak juga dimanfaatkan oleh para publisher untuk menerbitkan karya-karya tulis, yang pada gilirannya menerbitkan suasana persaingan dalam bisnis penerbitan dan percetakan. Bahkan teknologi percetakan itu juga mengancam Raja dengan diterbitkannya tulisan-tulisan yang mengkritik ajaran-ajaran gereja yang resmi, dan pandangan politik yang menyimpang dari kebijakan Raja. Tentu Raja menjadi tidak nyaman dengan suasana tersebut, yang kemudian menetapkan kebijakan untuk mengontrol penerbitan. Pada tahun 1534 Raja menerbitkan peraturan yang melarang siapa saja untuk menerbitkan karya tulis tanpa ijin dari lembaga sensor resmi.

Pada tahun 1557, Raja menganugerahkan kepada Stationers' Company (kelompok perusahaan penerbitan dan pedagang buku di London) hak monopoli untuk menerbitkan buku atau karya tulis cetakan. Namun hak monopoli itu hanya berlangsung sampai tahun 1694 dengan pencabutan hak tersebut. Akibatnya, perusahaan-perusahaan penerbitan itu merasa terancam oleh bahaya kompetisi. Oleh sebab itu kemudian mereka melakukan loby kepada pembentuk undang-undang pada saat itu untuk memberikan perlindungan hukum kepada mereka dengan alasan bahwa jika mereka tidak diberikan perlindungan, maka akibatnya terjadi anarchy yang pada gilirannya akan terjadi economic disaster. Loby mereka berhasil. Pada tahun 1710 ,

${ }^{3}$ Pada masa itu negara Indonesia memang belum lahir. Wilayah Indonesia saat itu masih disebut dengan Hindia Belanda (Netherlands Indie).

${ }^{4}$ Isi Pasal 131 ayat (2.a) IS adalah sbb: "Dalam ordonansi-ordonansi yang mengatur Hukum Perdata dan dagang ini: (a) untuk golongan Eropa berlaku undang-undang yang berlaku di Negeri Belanda ...". Bahasa Belandanya adalah sbb: "In de ordonnanties regelende het burgerlijk - en handelsrecht worden: (a) voor de Europeanen de in Nederland geldende wetten gevolgd. ...". Lihat De Wetboeken, "Wetten en Verordeningen, Benevens de Grondwet van de Republiek Indonesie", (Jakarta: Ichtiar Baru van Hoeve), 1989, hal. 143. 
pembentuk undang-undang menerbitkan Copyright Act 1710 atau yang lebih dikenal dengan The Statute of Anne tahun $1710 .^{5}$

Dari kisah ini tampak bahwa munculnya gagasan perlindungan copyright di Inggris memang tidak ada kaitannya dengan Pencipta. Copyright muncul karena kepentingan ekonomi dari para anggota kelompok perusahaan yang tergabung dalam Stationers' Company terancam.

Perlindungan copyright di Inggris melahirkan perdebatan, terutama di negara-negara Eropa daratan (Eropa Continental). Perdebatan itu dilandasi pemikiran tentang keadilan. Alangkah tidak adil jika pencipta yang melahirkan karya tulis justru tidak mendapatkan perlindungan. Mengapa hanya industri penerbitan yang mendapat hak mengcopy (copyright)? Bukankah Martial (penyair Romawi) pernah mengecam keras ketika karya tulisnya berupa sajak-sajak dibacakan di depan umum tanpa ijin darinya? ${ }^{6}$ Dengan demikian secara moral sesungguhnya pencipta lebih berhak untuk mendapatkan perlindungan ketimbang penerbit.

Itu sebabnya di negara-negara Eropa Kontinental kemudian muncul gagasan untuk memberikan perlindungan kepada pencipta berupa droit de auteur (Prancis) atau autersrecht (Belanda). Itulah pula sebabnya disamping hak ekonomi berupa hak memperbanyak dan menerbitkan (copy and publish) seorang pencipta juga memiliki hak moral untuk mendapatkan perlindungan berupa perlekatan (right of attribution) antara dirinya dan ciptaannya. Suatu karya cipta tidak boleh dipisahkan dari penciptanya. Oleh sebab itu nama pencipta harus senantiasa dilekatkan pada ciptaannya (doctrine of patternity). Suatu ciptaan juga tidak boleh diubah-ubah tanpa persetujuan penciptanya (doctrine of integrity).

Hak moral semacam itu tidak dikenal dalam sistem hukum Inggris, ${ }^{7}$ khususnya dalam sistem copyright, karena masalah copy mengcopy memang tidak ada kaitannya dengan hak moral penciptanya. Fokus utamanya bukan pada masalah penciptaan, tetapi pada masalah siapa yang berhak memperbanyak untuk diterbitkan (right to copy and right to publish). Pandangan semacam inilah yang kemudian mendapatkan kritik di negara-

${ }^{5}$ Selengkapnya tentang sejarah copyright, baca Craig Joyce, et al., "Copyright Law", $5^{\text {th }}$ ed., (Matthew Bender \& Co., Inc, member of LexisNexis, 2001), hal. 15-19.

${ }^{6}$ Lihat Paul Goldstein, "Hak Cipta: Dahulu, Kini, dan Esok", (Jakarta: Yayasan Obor, 1996), hal. 42-43. Judul asli "Copyright's Highway, From Gutenberg to the Celestial Jukebox".

${ }^{7}$ Walaupun dalam perkembangannya kemudian sudah mulai muncul konfergensi di antara sistem copyright dan author's right. Baca Martha Woodmansee \& Peter Jaszi, ed., "The Construction of Authorship", (Durham and London: Duke University Press, 1994). 
negara Eropa Kontinental. Menurut doktrin tentang keadilan, yang seharusnya diberikan hak untuk memperbanyak dan menerbitkan adalah pencipta, bukan penerbit. Itulah sebabnya istilah yang digunakan di negaranegara Eropa Kontinental bukanlah copyright, melainkan author's right (droit de auteur).

Ajaran hukum berlandaskan moral inilah yang kemudian diwujudkan dalam bentuk undang-undang, yang di Belanda dituangkan dalam Auteurswet 1912. Di Indonesia istilah auteursrecht (author's right) kemudian diterjemahkan menjadi Hak Pencipta atau disingkat Hak Cipta. Dengan demikian jelaslah bahwa di Indonesia doktrin yang berlaku bukanlah copyright model Inggris, melainkan aurhor's right model Eropa Kontinental. Namun harus dipahami bahwa di dalam istilah Hak Cipta itu tetap terkandung hak memperbanyak (copy) dan hak menerbitkan (publish), karena memang hak-hak itulah yang harus diberikan kepada pencipta, dan bukan kepada penerbit. Dengan doktrin ini, pencipta adalah pemilik hak memperbanyak (copy) ciptaan dan mempublikasikan ciptaannya untuk tujuan memperoleh manfaat ekonomi daripadanya.

Hak untuk memperbanyak (copy) dan hak untuk mempublikasikan (publish) ini memang dapat diberikan kepada orang lain melalui perjanjian. Perjanjian semacam ini dinamakan license agreement (pemberian ijin/lisensi). Namun demikian kepemilikan hak tetap berada pada pencipta. Secara alamiah, ciptaan memang tidak dapat dipisahkan dari penciptanya. Secara moral, seorang pencipta memiliki hak mutlak atas ciptaannya yang tidak dapat dialienasikan (dipisahkan). Itulah konsep dasar hak moral yang dikembangkan di negara-negara Eropa Kontinental berdasarkan ajaran hukum alam.

Contoh dari konsep dasar ini antara lain berupa perlekatan antara ciptaan dengan penciptanya. Hal ini bersifat alamiah. Misalnya, lukisan Monalisa sampai kapan pun tetap merupakan hasil karya Leonardo Da Vinci. Lagu Bengawan Solo, sampai kapan pun tetap merupakan karya Gesang. Novel Ada Apa Dengan Cinta sampai kapanpun adalah karya Habiburrahman.

\section{Substansi Hak Cipta}

Menurut Undang-undang Hak Cipta No. 19 Tahun 2002 (UUHC 2002), Hak Cipta adalah hak eksklusif dari pencipta untuk mengumumkan dan memperbanyak ciptaan, termasuk hak untuk memberikan lisensi atau melarang pihak lain menggunakan ciptaan tanpa ijin (lisensi). ${ }^{8}$ Bandingkan 
dengan US Copyright Law yang tidak memberikan definisi tentang copyright, melainkan hanya memberikan definisi tentang copyright owner. ${ }^{9}$ Hal ini dapat dimengerti karena Amerika Serikat memang menggunakan pendekatan ownership ketimbang authorship. Hal yang sama juga dianut di Inggris yang menjadi acuan common law system yang berlaku di Amerika Serikat. ${ }^{10}$ Copyright Act Inggris juga tidak mencantumkan definisi copyright secara tegas sebagaimana UUHC. Di kedua negara induk semang common law system itu, yang lebih ditekankan adalah substansi hak dari pemilik copyright, dan bukan substansi hak dari pencipta. Hal ini selaras dengan sejarah copyright itu sendiri, yang sudah diuraikan secara singkat di atas. ${ }^{11}$

Berdasarkan definisi UUHC tentang Hak Cipta dapat dipahami bahwa hak cipta adalah hak untuk mengumumkan (publish) dan memperbanyak (copy) ciptaan. Itu berarti bahwa menurut UUHC, copyright merupakan salah satu substansi dari hak cipta. Esensi hak cipta memang adalah hak untuk mendapatkan manfaat ekonomi secara eksklusif dari eksploitasi ciptaan yang bersangkutan. Cara untuk dapat memanfaatkan ekonomi suatu ciptaan adalah dengan memperbanyak (copy) dan kemudian mempublish, atau membuat ciptaan itu dapat dinikmati oleh publik (making available for public). Seorang pencipta lagu tidak akan mendapatkan manfaatkan ekonomi dari lagu tersebut bila tidak memperdengarkan (publish) lagu tersebut kepada

${ }^{8}$ Lihat Pasal 1 butir (1) UU No. 19 Tahun 2009 tentang Hak Cipta (UUHC). Isi selengkapnya dari pasal tersebut adalah sbb:

Hak Cipta adalah hak eksklusif bagi Pencipta atau penerima hak untuk mengumumkan atau memperbanyak ciptaannya atau memberikan ijin untuk itu dengan tidak mengurangi pembatasan-pembatasan menurut peraturan perundangundangan yang berlaku.

${ }^{9}$ Lihat $\delta 101$ US Copyright Act: Copyright owner with respect to any one of the exclusive rights comprised in a copyright, refers to the owner of that particular right. Sedikitpun tidak menyebut apakah copyright itu.

${ }^{10}$ Dahulu Amerika Serikat adalah koloni Inggris, sehingga hukum yang berlaku juga bersumber dari hukum Inggris. Sistem perlindungan copyright di Inggris ini diadopsi ke dalam sistem Amerika Serikat pada tahun 1790 dengan diberlakukannya Copyright Act of The United States 1790. Lihat J.A.L. Sterling, "World Copyright Law", (London: Sweet \& Maxwell, 1998), hal. 5 .

11 Dalam general summary, Sterling menyimpulkan bahwa copyright adalah: "the right granted for the protection of literary, dramatic, musical and artistic works, and other works resulting from the author's own intellectual creation". Sterling tidak menggunakan istilah works of author, melainkan works resulting from the author's intellectual creation. Artinya, Sterling pun tidak dengan tegas mengakui bahwa mestinya copyright adalah the right of author. Hal ini dapat dipahami mengingat acuan utama Sterling adalah copyright system dari Inggris. Lihat kembali Sterling, Ibid., hal. 4. 
publik. Memperdengarkan itu dapat dilakukan melalui live performance atau melalui pemutaran ulang rekaman suara lagu tersebut.

Untuk dapat memutar ulang di berbagai tempat, tentu lagu tersebut harus direkam dan diperbanyak (copy). Supaya rekaman lagu itu layak dengar dan memiliki kualitas dan keindahannya sendiri, maka lagu itu harus direkam sedemikian rupa dengan menggunakan peralatan yang memadai, dan dibawakan oleh artis atau musisi yang memiliki skill tertentu. Di sinilah kemudian muncul hak-hak yang terkait dengan proses menampilkan lagu tersebut kepada publik (making available for public).

Memperbanyak dan mengumumkan adalah hak sepenuhnya dari seorang pencipta. Hanya saja, pada saat memperbanyak dalam format yang bagus, biasanya pencipta melibatkan artis dan musisi serta perusahaan rekaman dengan memberikan lisensi (ijin) kepada mereka untuk melakukannya. Kemudian perusahaan rekaman membuat master, yang untuk dijual harus melalui proses perbanyakan (copying). Dalam hal ini, perusahaan rekaman mendapatkan copyright atas master rekaman tersebut. Sedangkan artis mendapatkan hak untuk menampilkan (performing) lagu tersebut, baik dalam bentuk rekaman itu sendiri maupun dalam bentuk live performance pada waktunya nanti. Inilah yang disebut performing rights dari pelaku (artis/musisi).

Dalam konteks inilah kemudian timbul istilah-istilah teknis dalam bidang hak cipta, yaitu: ciptaan (works) berupa lagu, dan karya rekaman suara (phonograms atau sound recordings). Untuk ciptaan, hak sepenuhnya berada di tangan pencipta, baik hak ekonomi maupun hak moral. Sedangkan untuk karya rekaman suara (master rekaman), copyright-nya berada di tangan perusahaan rekaman atas dasar lisensi dari pencipta. Pelaku juga diberi hak atas perbanyakan karya rekaman tersebut, disamping hak performing atas rekaman suara yang bersangkutan. Dengan kata lain, di dalam sebuah karya rekaman lagu terdapat beberapa hak yang bertumpuk di dalamnya, yaitu: (1) hak cipta (author's right) dari pencipta atas ciptaannya yang juga mencakup hak ekonomi dan hak moral sekaligus, (2) hak perbanyakan (copyright) dari perusahaan rekaman atas karya rekamannya (sound recording), dan (3) hak performing dari pelaku atas karya rekaman tersebut.

Copyright dari perusahaan rekaman atas karya rekamannya biasanya bersifat mechanical, sehingga seringkali disebut bahwa perusahaan rekaman mempunyai mechanical rights atas sound recording yang bersangkutan. ${ }^{12}$ Mechanical right biasanya berurusan dengan mechanical process dalam konteks copy mengcopy. Bermula dari lagu (works) yang diciptakan oleh

${ }^{12}$ Mechanical right is a more or less colloquial term to describe the right of author to authorise the sound recording of his work. Lihat Sterling, Ibid., hal. 778. 
pencipta, kemudian ijin (mechanical lisence) ${ }^{13}$ diberikan kepada perusahaan rekaman untuk melakukan proses pembuatan master rekaman (phonograms). Pada masa sebelum era digital, proses perekaman lagu melibatkan suatu proses mekanikal untuk menghasilkan suatu karya rekaman dengan kualitas tertentu. Dalam konteks inilah pencipta memberikan lisensi berupa mechanical right kepada perusahaan rekaman. Contoh yang populer sekarang ini misalnya berhubungan dengan bisnis ringtone (bukan ring back tone). Bisnis ringtone akan melibatkan mechanical right dari perusahaan rekaman.

Hal-hal tersebut di atas dapat menimbulkan pertanyaan lanjutan, apakah pencipta tidak lagi memiliki hak atas karya rekaman (sound recording) yang bersangkutan? Jawabnya, sepanjang menyangkut copyright atas sound recording, biasanya berdasarkan perjanjian perekaman suara hak tersebut sudah diserahkan kepada perusahaan rekaman. Perjanjian ini biasanya membatasi hak pencipta untuk tidak memberikan hak yang sama kepada perusahaan lainnya. Ini yang biasanya disebut lisensi dengan hak eksklusif (exclusive rights). Dengan demikian, selama jangka waktu perjanjian, bahkan pencipta sendiri tidak boleh lagi memperbanyak karya rekaman yang bersangkutan tanpa persetujuan perusahaan rekaman.

Namun perlu dipahami bahwa meskipun Pencipta tidak mempunyai copyright atas karya rekaman (sound recording) yang bersangkutan, akan tetapi Pencipta tetap menjadi pemilik atas karya cipta (works) yang terdapat di dalam karya rekaman yang bersangkutan. Dengan demikian, ia tetap dapat memberikan ijin kepada pihak lainnya untuk merekam karya cipta yang bersangkutan dalam genre musik yang berbeda. Sebagai contoh, jika kepada perusahaan A, Pencipta memberikan lisensi untuk memperbanyak lagunya yang dibuat dalam genre musik pop, maka Pencipta masih memiliki hak untuk memberikan lisensi kepada perusahaan B untuk memperbanyak lagunya yang dibuat dalam genre musik keroncong atau dangdhut. Demikian seterusnya.

Adapun mengenai hak mengumumkan (right of communication to public) lagu (works), selamanya tetap berada di tangan pencipta. Itu sebabnya, meskipun copyright telah diserahkan kepada perusahaan rekaman, namun ketika lagu yang terdapat di dalam karya rekaman itu diputar atau diperdengarkan di tempat-tempat publik, seperti di hotel, restauran, karaoke, dan lain-lainnya, termasuk melalui media cellular phone seperti dalam ring back tone (RBT), pencipta tetap berhak untuk mendapatkan royalti atas pemutaran lagu tersebut. ${ }^{14}$ Di samping itu, pelaku juga mempunyai hak atas

${ }^{13}$ Tentang mechanical lisence, baca Craig Joyce, et al., Ibid., hal. 511.

${ }^{14}$ Baca Pasal 2 ayat (1) UUHC 2002. 
kegiatan memperdengarkan karya rekaman tersebut di tempat publik. ${ }^{15}$ Oleh karenanya, baik artis/musisi maupun pencipta, keduanya berhak atas pembayaran royalti atas pemutaran lagu tersebut di tempat-tempat umum, khususnya yang terkait dengan kegiatan komersial, seperti di hotel, restauran, karaoke, RBT, dsb. Hal ini disebabkan karena penyerahan copyright dari pencipta kepada perusahaan rekaman maupun artis tidak berarti menyerahkan pula hak mengumumkan (publishing right) atas lagu (works) yang bersangkutan. Namun perlu dicatat bahwa publishing rights yang dimaksud di sini hanya terbatas pada hak memperdengarkan lagu (right of communication to public). Sedangkan publishing right dalam arti mendistribusikan, menjual, dan menyewakan sound recording atau yang sering disebut sebagai kegiatan making available for public, hak itu juga diberikan kepada perusahaan rekaman yang bersangkutan. Adalah tidak logis bila perusahaan rekaman yang telah membuat master rekaman tidak boleh menjual hasil rekamannya (sound recording) kepada publik.

Dengan uraian di atas kiranya menjadi jelas bahwa dalam konteks ciptaan yang berbentuk suara (audio) terdapat beberapa bentuk ekspresi, yaitu ciptaan (works) yang tetap menjadi haknya si pencipta, dan sound recording, yang menjadi haknya perusahaan rekaman dan artis pelakunya. Untuk jelasnya dapat dipaparkan dalam bentuk diagram sebagai berikut:

${ }^{15}$ Baca Pasal 49 ayat (1) UUHC 2002. Dalam WIPO Copyright Treaty 1996 disebut sebagai Right of Communication to Public. 


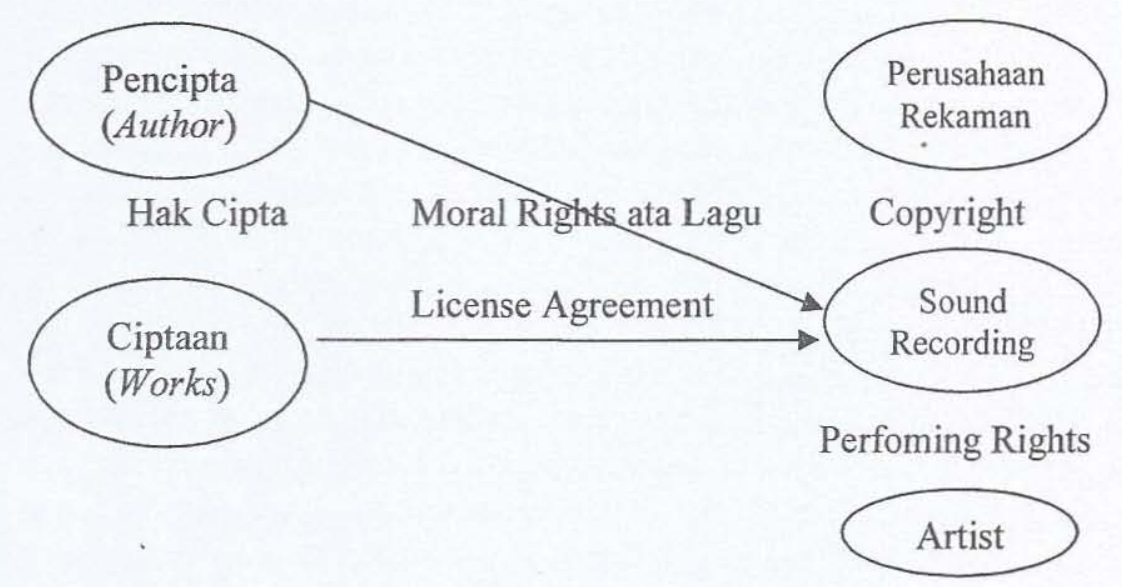

Adapun dalam konteks ciptaan yang berbentuk karya tulis (literary works), detailnya agak sedikit berbeda, khususnya dalam konteks hak untuk mengumumkan. Seorang pencipta karya tulis (literary works) selamanya mempunyai hak cipta atas karya tulis tersebut yang berupa naskah (script). Namun demikian, ketika naskah itu kemudian diserahkan kepada book publisher untuk dicetak dan diterbtkan dalam bentuk buku, maka biasanya kepada book publisher itu diberikan hak untuk memperbanyak (copyright). Dengan demikian, dalam sebuah buku terdapat dua hak yang melekat, yaitu: hak cipta atas naskah yang tetap berada di tangan pencipta, dan hak memperbanyak (copyright) atas bukunya yang berada di tangan book publisher.

Perbedaan antara hak cipta atas naskah dengan copyright atas buku dapat dengan mudah dibedakan ketika dikaitkan dengan hak untuk mengubah ciptaan yang masuk ke dalam wilayah hak moral. Misalkan novel Bumi Manusia karya Pramoedya Ananta Toer akan diterjemahkan ke dalam bahasa Prancis, maka ijin mengubah naskah novel tersebut ke dalam bahasa Prancis hanya dapat diberikan oleh Pramoedya sebagai pencipta, dan bukan dari penerbit novel tersebut, walaupun penerbit mempunyai (copyright) yang berasal dari Pram sebagai penulis naskahnya (script). Demikian pula halnya bila ada yang berminat mengubah ekspresi karya Pramoedya dari literary works menjadi visual works (dalam bentuk film misalnya), maka ijin itu tidak dimintakan dari penerbit, melainkan dari penulis naskah. 
Yang perlu dicatat adalah bahwa antara hak moral dengan hak ekonomi sesungguhnya tidak dapat dipisahkan. ${ }^{16}$ Misalnya, hak untuk memberikan ijin mengubah ekspresi ciptaan yang sepenuhnya menjadi hak pencipta, walaupun hak ini masuk ke dalam kategori moral right, namun ijin itu dapat saja dikaitkan dengan fee atau royalty yang harus dibayar oleh orang yang akan mengubah karya cipta tersebut. Sebagai contoh, untuk menterjemahkan karya J.K. Rowling berjudul Harry Potter ke dalam bahasa Indonesia terlebih dahulu harus mendapatkan ijin dari pencipta (moral right). Tentu saja ijin itu dapat diberikan setelah ada kesepakatan tentang jumlah royalty (economic right) kepada Rowling sebagai pencipta. Pemisahan antara hak moral dan hak ekonomi dengan demikian hanya relevan dalam konteks kajian akademis untuk mempermudah pemahaman saja. ${ }^{17}$ Namun hal yang terpenting dari gagasan moral right adalah bahwa hak itu merupakan personality right dari seorang pencipta atas ciptaannya. Hak ini mencerminkan integritas dan ketidakterpisahan antara pencipta dengan ciptaannya. ${ }^{18}$

\section{Hak Cipta dalam Related Rights}

Related rights atau hak-hak terkait adalah hak yang bersifat sekunder. Dikatakan hak sekunder atau hak terkait karena pada umumnya memang hak ini terkait dengan hak-hak pencipta (hak cipta / author's rights). ${ }^{19}$ Misalnya, hak cipta atas lagu dapat melahirkan hak terkait berupa performer's rights apabila pencipta memberikan ijin kepada artis untuk menampilkan (to perform) lagu yang bersangkutan, baik dalam suatu live show maupun dalam

${ }^{16}$ Pandangan ini berkembang di Jerman yang tidak memisahkan antara hak moral dan hak ekonomi dari seorang Pencipta atas ciptaannya. Lihat J.A.L. Sterling, Op. Cit., hal. 38.

${ }^{17}$ Pemisahan antara hak moral dan hak ekonomi (dualist theory) berasal dari Prancis yang membedakan antara hak moral dan hak ekonomi. Sterling, Ibid., h.38.

${ }^{18}$ Kajian yang mendalam tentang konsep hak moral ini dapat disimak dalam Sterling, Ibid., h.279-303.

19 Perlu dicatat bahwa meskipun pada umumnya hak terkait memang terkait dengan hak-hak pencipta, namun dalam beberapa hal hak terkait, seperti hak siar (broadcasting rights), dapat pula berdiri sendiri sebagaimana halnya dalam contoh hak siar atas pertandingan sepak bola. Tentu saja para pemain bola bukanlah pencipta permainan sepak bola, melainkan hanya pelaku olah raga sepak bola. Dalam sistem hukum Indonesia, pengaturan hak terkait dimasukkan ke dalam Undang-undang No. 19 Tahun 2002 tentang Hak Cipta (UUHC), khususnya dalam Bab VII tentang Hak Terkait (Pasal 49 s/d 51). 
bentuk karya rekaman. Hak cipta atas lagu juga dapat melahirkan hak terkait berupa producer's rights ketika pencipta lagu itu memberikan ijin kepada recording company untuk membuat master rekaman (sound recording / phonograms) lagu tersebut bersama-sama dengan artis.

UUHC 2002 mengenal 3 macam hak terkait, yaitu: hak pelaku (performer's rights), hak produser rekaman suara (producer's rights), dan hak siar (broadcasting rights) dari lembaga penyiaran. ${ }^{20}$ Dalam sistem hukum internasional, hak terkait diatur secara terpisah dari hak cipta. Hak ini disepakati dalam Rome Convention 1980 maupun WIPO Performances and Phonograms Treaty (WPPT) 1996. Sedangkan Hak cipta dalam sistem hukum internasional disepakati dalam Berne Convention dan WIPO Copyright Treaty 1996 (WCT).

Lahirnya hak terkait (related rights) yang bersumber dari hak cipta pada umumnya terkait dengan komersialisasi suatu karya cipta, khususnya musik atau lagu. Hal itu terjadi ketika pencipta lagu memberikan ijin kepada pelaku dan produser untuk membuat karya rekaman suara atas lagu yang bersangkutan. Dalam konteks ini, pencipta memberikan hak kepada pelaku dan produser untuk memperbanyak (copy) dan mendistribusikan (right of distribution) hasil rekaman suara itu untuk dijual (making available for public). Dengan demikian, baik pelaku maupun produser mendapatkan copyright atas karya rekaman suara itu (copyright on phonograms) dari pencipta. Sementara itu pencipta tetap menjadi pemilik hak cipta (author's right) atas lagu (works) yang bersangkutan.

Perbedaan copyright dari produser dengan author's right dari pencipta tersebut akan mudah dipahami dalam contoh ketika suatu lagu ciptaan A misalnya hendak diubah genre musiknya ke dalam genre yang berbeda, sebagaimana telah disinggung di atas. Misalnya, A menciptakan lagu dengan genre musik rock. Lagu itu sudah direkam oleh perusahaan X. Dalam hal ini A adalah tetap sebagai pemilik hak cipta (author's rights) sedangkan X adalah pemegang copyright atas sound recording yang bersangkutan. Apabila ada pihak lain (B) ingin mengubah genre musik itu menjadi musik dangdut, maka B harus meminta ijin kepada A, dan bukan kepada X. Di sinilah tampak bahwa meskipun $\mathrm{X}$ menjadi pemegang copyright atas karya rekaman lagu ciptaan $\mathrm{A}$, namun ia tidak memiliki hak atau wewenang untuk memberi ijin kepada B untuk mengubah genre musiknya ke dalam genre yang berbeda. Hak itu sepenuhnya milik A dan tetap berada pada A.

Gambar berikut mungkin dapat mempermudah pemahaman tersebut: 


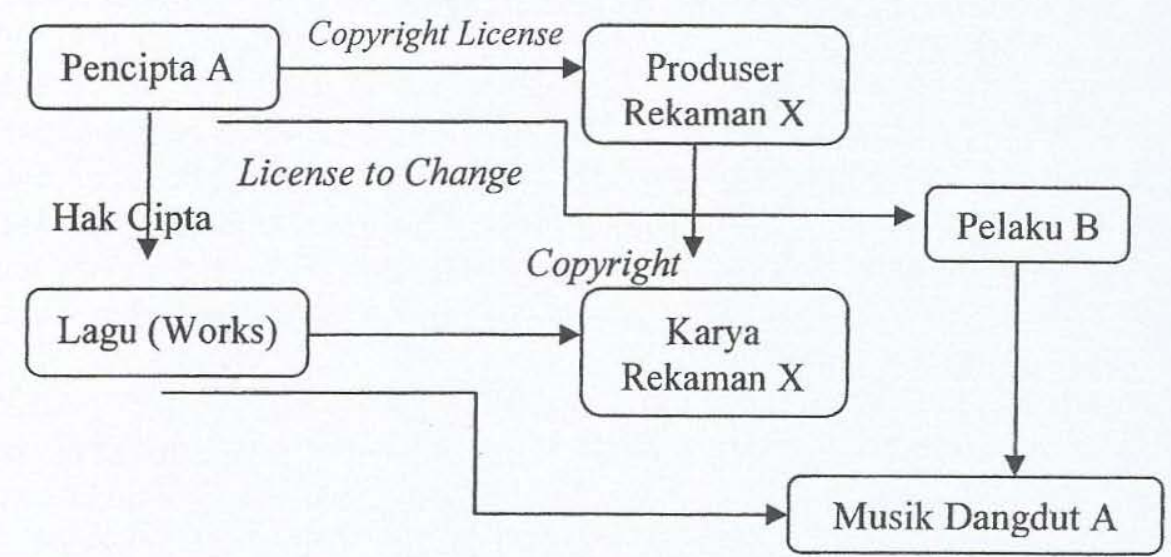

Dalam contoh di atas, Pelaku B yang mengubah lagu A dari genre rock menjadi lagu dangdut dapat menunjuk perusahaan Y untuk merekam lagu dangdut tersebut. Dalam hal ini A memberi ijin (license) kepada B untuk mengubah ciptaan berdasarkan doktrin moral right, sekaligus memberikan ijin kepada B untuk memperbanyak lagu A itu (copyright) yang telah diubah genrenya menjadi genre dangdut. Atas ijin tersebut B dapat memberikan imbalan ekonomi kepada $\mathrm{A}$ berupa royalty atas pengubahan dan perbanyakan (copy) lagu A tersebut.

Contoh-contoh di atas memberikan penjelasan kepada kita bahwa di dalam hak cipta terdapat hak untuk memperbanyak (copyright) yang oleh penciptanya dapat diberikan kepada siapa saja untuk memperbanyak karya cipta dalam bentuknya yang baru (bentuk karya rekaman). Meskipun kemudian produser rekaman mempunyai copyright atas karya rekaman, hal itu tidak mengurangi hak pencipta untuk memberikan ijin kepada pihak lain untuk mengubah karya cipta yang bersangkutan. Kepada pihak ini juga tetap dapat diberikan ijin memperbanyak hasil perubahannya itu. Dengan demikian menjadi jelas bahwa pencipta sebagai pencipta dapat memberikan ijin kepada berbagai pihak untuk mengcopy karya ciptanya dalam bentuk yang berbedabeda. Sedangkan pihak yang diberi copyright oleh pencipta itu hanya mempunyai copyright atas bentuk ekspresi masing-masing, sebagaimana halnya contoh-contoh di atas. 


\section{Beberapa Hal Penting Terkait Dengan Konsep Perbanyakan Dan Pengumuman}

Perbanyakan (copying) seringkali dimaknai juga dengan istilah reproduction. Undang-undang Hak Cipta 2002 menggunakan istilah perbanyakan yang berarti penambahan jumlah suatu ciptaan, baik secara keseluruhan maupun bagian yang sangat substansial dengan menggunakan bahan-bahan yang sama ataupun tidak sama, termasuk mengalihwujudkan secara permanen atau temporer. ${ }^{21}$

Pengertian yang disebutkan dalam Pasal 1 butir (6) UUHC 2002 sebenarnya tidak atau belum jelas. Namun dalam Penjelasan resmi tidak ditemukan penjelasannya. Sehingga kita tidak dapat menjumpai tafsir otentik atas kata 'mengalihwujudkan'. Padahal makna mengalihwujudkan dalam doktrin hak cipta mengandung makna terjadinya perubahan bentuk ekspresi, misalnya dari literary works menjadi visual works, sebagaimana dalam contoh pengalihan novel ke dalam bentuk film (cinematografi). Perubahan bentuk semacam itu tentu saja tidak dapat dikatakan sebagai mengcopy.

Oleh sebab itu ada baiknya memahami lebih lanjut kata perbanyakan itu dengan mengeksplorasi makna reproduction yang dimaksud dalam US Copyright Law, sekadar sebagai perbandingan. Ternyata setelah ditelusuri, US Copyright Law tidak mendefinisikan secara tunggal makna reproduction sebagaimana dilakukan UUHC 2002. Hal ini dapat dipahami mengingat bentuk-bentuk reproduction memang berbeda-beda, bergantung pada bentukbentuk karya cipta itu sendiri. Reproduction of literary works tentu sangat berbeda dengan reproduction of musical works, dan seterusnya.

Dalam sistem UU Hak Cipta Amerika Serikat reproduction means: reproduce a material object in which the work is duplicated, transcribed, imitated or simulated in a fixed form, from which it can be perceived, reproduced, or otherwise communicated, either directly or with the aid of a machine device. ${ }^{22}$ Dari makna tersebut dapat diketahui bahwa reproduction meliputi duplication, transcription (sebagai contoh, perubahan dari huruf stenografi ditransliterasi menjadi huruf alphabetic, imitation (peniruan), dan simulation. Duplication biasanya diartikan sebagai penambahan jumlah dari satu menjadi dua, demikian seterusnya. Adapun produk yang diduplikasi itu sendiri tidak mengalami perubahan apapun. Contoh adalah memfotocopy suatu dokumen tertulis atau buku.

\section{2).}

${ }^{21}$ Pasal 1 butir (6) Undang-undang No. 19 Tahun 2002 tentang Hak Cipta (UUHC

${ }^{22}$ Craig Joyce, et al., Ibid., hal. 497. 
Dalam ranah praksis, duplikasi karya cipta merupakan tindakan yang paling banyak dilakukan, termasuk yang dilakukan oleh para pembajak buku atau rekaman suara atau video. Tindakan inilah yang sering disebut sebagai piracy of copyrighted works. Perlu dipahami bahwa penambahan jumlah melalui duplikasi itu bisa saja dilakukan dengan menggunakan media yang berbeda. Misalnya, semula naskah tertulis dalam bentuk tercetak di atas kertas sebagaimana buku pada umumnya (hard copy). Kemudian naskah itu diduplikasi dengan menggunakan media elektronik (soft copy). Dengan pemahaman inilah arti kata now known or later develop yang disebutkan dalam US Copyright Law mendapatkan wujudnya yang konkrit. Artinya, media ekspresi karya cipta memang dapat berubah-ubah sesuai dengan kemajuan teknologi penyimpanan data. Jika pada jaman dahulu tak terbayangkan untuk menyimpan seribu buku dalam sebuah flash disk yang dapat digenggam karena sangat kecil, maka pada masa sekarang ini media flash disk menjadi hal yang biasa saja. Mungkin di masa yang akan datang akan ada lagi suatu bentuk alat atau media penyimpan data yang semakin praktis. Namun dalam konteks duplikasi karya cipta, apapun medianya, yang penting karya cipta yang bersangkutan dapat diduplikasi tanpa mengubah bentuk aslinya, yaitu literary works, musical works, ataupun visual works.

Selanjutnya, transcribing dimaksudkan sebagai suatu perbuatan mengubah jenis huruf, bahasa (translation) dan bahkan bentuk ekspresi yang memungkinkan. Sebagai contoh tindakan yang terakhir adalah mentranskrip naskah dari yang berbentuk audio menjadi literal. Misalnya, mentranskrip berita acara rapat yang direkam untuk kemudian dituangkan dalam bentuk tertulis di atas kertas atau elektronik.

Sedangkan imitation atau simulation biasanya dimaknai sebagai suatu bentuk peniruan dengan mengambil bagian-bagian yang penting dari sebuah ciptaan kemudian ditambahkan atau dikombinasikan menjadi wujud yang agak berbeda, tetapi mengandung unsur-unsur yang sama. Gambar Monalisa berikut ini adalah contoh imitasi atau simulasi suatu ciptaan menjadi ciptaan yang lain. 

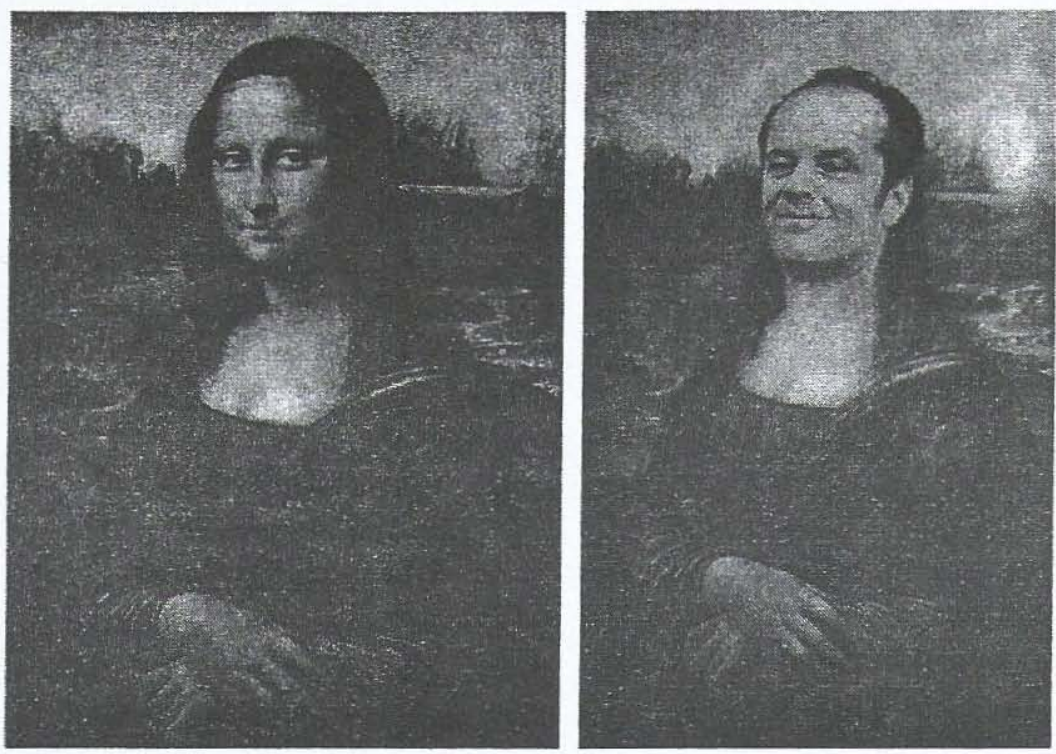

sumber: www.google.com

Dua gambar di atas, di samping menunjukkan unsur yang berbeda, yaitu pada bagian kepala, namun secara keseluruhan gambar tersebut memiliki unsur-unsur yang sama. Dua gambar itu boleh jadi dibuat dalam media yang berbeda, misalnya Monalisa yang asli jelas dibuat di atas kanvas, sedangkan gambar tiruannya dibuat dalam bentuk digital atau data elektronik. Namun bagaimana pun, kedua gambar tersebut memiliki kemiripan yang kuat, kecuali pada bagian kepada yang memang sudah diganti oleh pembuatnya. Siapapun dengan mudah mengatakan bahwa gambar kedua adalah tiruan (a simulation atau imitation) dari gambar pertama.

Mungkin saja di dalam contoh-contoh yang berbeda masalah imitation atau simulation ini tidak begitu sederhana untuk menentukan apakah gambar yang satu merupakan simulasi dari gambar yang lain. Apalagi jika bentuk ekspresinya adalah karya literal atau cinematografi. Misalnya saja, pernah dipermasalahkan adanya sinetron Indonesia yang meniru (imitate) sinetron dari luar yang berjudul One Liter Tears (OLT). Dalam contoh ini jelas tidak ada duplikasi, dalam arti menggandakan tangible form dari film OLT. Namun orang yang menonton kedua film tersebut dalam waktu yang berdekatan akan dengan mudah menemukan adanya unsur-unsur yang sama, entah dalam setting atau pun alur cerita.

Dengan paparan di atas menjadi jelas bahwa copyright utamanya berhubungan dengan persoalan reproduction karya cipta dalam bentuknya 
yang terus berkembang, seiring dengan perkembangan tekonologi. Sementara itu author's right lebih menekankan pada hak-hak pencipta yang tidak saja berkenaan dengan persoalan reproduction, melainkan menyangkut pula halhal yang berhubungan dengan integritas dan reputasi pencipta.

Selain perbanyakan, unsur lain yang penting dalam doktrin Hak Cipta adalah masalah pengumuman. UUHC 2002 mencampur-adukkan pengertian pengumuman sebagaimana dapat dibaca dalam Pasal 1 butir (5) sebagai berikut:

Pengumuman adalah pembacaan, penyiaran, pameran, penjualan, pengedaran, atau penyebaran suatu Ciptaan dengan menggunakan alat apapun, termasuk media internet, atau melakukan dengan cara apapun sehingga suatu Ciptaan dapat dibaca, didengar, atau dilihat orang lain.

Sesungguhnya terdapat makna yang berbeda antara pengumuman dalam arti distribusi tangible form dari suatu ciptaan dengan menampilkan (perform) atau menyiarkan (broadcast) atau memperlihatkan (display) suatu ciptaan. Makna distribusi mencakup penjualan, penyewaan, yang memungkinkan suatu media karya cipta (tangible form) dapat dimiliki oleh orang lain. Misalnya, $\mathrm{CD}$ yang berisi karya musik dapat dibeli di toko-toko musik. Buku yang berisi naskah atau gambar-gambar dapat dimiliki oleh seseorang dengan membelinya dari toko-toko buku. Demikian seterusnya. Adapun memperdengarkan atau menampilkan (to perform untuk musical works), menyiarkan (to broadcast untuk lagu atau film), atau memajang (to display untuk karya lukis atau patung) suatu karya cipta tidak memungkinkan pendengarnya atau pemirsa menjadi pemilik atas tangible form dari bentukbentuk karya cipta tersebut, kecuali jika pemilik tangible formnya tersebut berniat menjual.

Dalam konteks distribusi, objeknya adalah benda fisik (tangible form) dari media yang menyimpan karya cipta yang bersangkutan. Benda tersebut, yang sejatinya adalah media penyimpanan karya cipta (yang intangible) kemudian diedarkan, dijual, atau disewakan kepada orang lain, yang memungkinkan orang lain itu memiliki untuk menikmati karya cipta yang bersangkutan. Sedangkan dalam performance atau display, objeknya adalah intangible, yaitu suatu kegiatan yang memungkinkan orang lain dapat mendengar, membaca, atau melihat suatu karya cipta.

Secara sederhana, makna pengumuman mencakup dua kategori, yaitu: (1) kegiatan yang memungkinkan orang lain memiliki benda yang menyimpan suatu karya cipta, dan (2) memperdengarkan, menampilkan, menyiarkan, atau mempertunjukkan suatu karya cipta sehingga orang lain 
dapat menikmati karya yang bersangkutan tanpa harus menguasai bendanya. Misalnya, seorang kolektor lukisan yang memamerkan lukisan-lukisan koleksinya dalam suatu pameran. Banyak orang yang datang untuk melihat koleksi lukisan tersebut. Dalam hal demikian, pemilik lukisan dikatakan sedang melakukan pengumuman dengan memajang (to display) lukisannya untuk dapat dilihat orang lain.

Hak untuk mendistribusikan suatu karya cipta biasanya terkait dengan hak untuk mereproduksi karya yang bersangkutan. Seseorang diberi hak untuk mereproduki, biasanya diikuti pula (bahkan kadangkala secara otomatis) dengan hak untuk mendistribusikan menjual produk yang bersangkutan. Sedangkan hak untuk memperdengarkan karya musik selamanya tetap berada pada pencipta. Sedangkan hak untuk memamerkan karya lukis mengikuti pemiliknya. Dengan demikian ada perbedaan yang signifikan antara mengumumkan karya musik dengan karya lukis. Oleh karena itu, pemahaman tentang pengumuman karya cipta harus dilihat case by case disesuaikan dengan bentuk karya cipta yang bersangkutan.

Berdasarkan pemahaman tersebut, maka ada baiknya jika kata pengumuman yang tercantum dalam UUHC 2002 tidak didefinisikan secara campur aduk sebagaimana yang terjadi saat ini.

\section{Penutup}

Artikel ini hendak menunjukkan kepada pembaca bahwa hak cipta bukan copyright. Hak cipta adalah hak yang di dalamnya terdapat hak memperbanyak (copyright). Hak cipta ini menurut sejarahnya memang merupakan koreksi terdapat doktrin copyright yang muncul di Inggris. Koreksi itu muncul di daratan Eropa berdasarkan doktrin keadilan (hukum alam) bahwa sudah sewajarnya yang lebih mendapatkan perlindungan adalah pencipta dan bukan perusahaan-perusahaan berbasis copyright. Perusahaan ini dilindungi hak-haknya yang bersumber dari pencipta. Oleh karena itu tidak pada tempatnya jika perusahaan-perusahaan ini justru berniat untuk mengambil alih semua hak-hak pencipta berdasarkan perjanjian.

Dalam hukum perjanjian juga terdapat prinsip bahwa perjanjian tidak boleh bertentangan dengan undang-undang. Artinya perjanjian tidak boleh menjadi sarana bagi industri untuk merampas hak-hak pecipta melalui lembaga perjanjian. Hak cipta dari seorang pencipta diberikan berdasarkan kekuatan undang-undang. Sudah sepatutnya hak-hak ini tidak dialienasikan dari penciptanya atas nama kebebasan berkontrak. Itulah sejatinya dari perlindungan hak-hak pencipta. 


\section{Daftar Pustaka}

Rosidi, Ajip. Undang-undang Hak Cipta 1982: Pandangan Seorang Awam. Jakarta: Djambatan, 1984.

Joyce, Craig, et al. Copyright Law, $5^{\text {th }}$ ed. Matthew Bender \& Co., Inc. 2001.

Sterling, J.A.L. World Copyright Law. London: Sweet \& Maxwell, 1998.

Goldstein, Paul. Copyright: Principles, Law and Practice. Little Brown \& Co., 1989.

Goldstein, Paul. Hak Cipta: Dahulu, Kini, dan Esok. Jakarta: Yayasan Obor, 1996.

Undang-undang No. 19 Tahun 2002 tentang Hak Cipta.

De Wetboeken, Wetten en Verordeningen, Benevens de Grondwet van de Republiek Indonesie. Jakarta: Ichtiar Baru van Hoeve, 1989.

Rome Convention 1980.

WIPO Performances and Phonograms Treaty 1996.

US Copyright Act 1976.

WIPO Copyright Treaty 1996. 